\title{
Impact of Hydroxychloroquine on Antibody Responses to the SARS-CoV-2 Coronavirus
}

\author{
Isabel Kinney Ferreira de Miranda Santos ${ }^{1 *}$ and Carlos Henrique Nery Costa ${ }^{2}$ \\ ${ }^{1}$ Ribeirão Preto School of Medicine, University of São Paulo, São Paulo, Brazil, ${ }^{2}$ Nathan Portela Institute of Tropical \\ Medicine, Federal University of Piauí, Teresina, Brazil
}

Keywords: COVID-19, Sars-CoV-2, coronavirus, antibodies, hydroxychloroquine

- Humoral immunity is a crucial aspect in mitigating the COVID-19 pandemic.

- Hydroxychloroquine and chloroquine are lysosomotropic drugs that affect antigen-presenting pathways and B-cell activation.

- Chloroquine inhibits antibody responses to vaccines, but reports about this effect apparently have not been called to the attention of investigators in the field of COVID-19.

- Studies on immunity to Sars-CoV-2 must take into account treatment regimens for COVID-19.

\section{INTRODUCTION}

OPEN ACCESS

Edited by:

Lucia Lopalco,

San Raffaele Hospital (IRCCS), Italy

Reviewed by:

Maria Tagliamonte,

Istituto Nazionale Tumori Fondazione

G. Pascale (IRCCS), Italy

*Correspondence: Isabel Kinney Ferreira de Miranda

Santos

imsantos@fmrp.usp.br

Specialty section:

This article was submitted to Viral Immunology,

a section of the journal

Frontiers in Immunology

Received: 04 June 2020

Accepted: 29 June 2020

Published: 30 October 2020

Citation:

de Miranda Santos IKF and

Costa CHN (2020) Impact of Hydroxychloroquine on Antibody Responses to the SARS-CoV-2

Coronavirus.

Front. Immunol. 11:1739.

doi: 10.3389/fimmu.2020.01739
Recent large observational studies indicate that hydroxychloroquine (HY) does not affect outcomes of patients hospitalized with COVID-19 $(1,2)$ and may even be harmful (3). Results of double-blind, randomized studies to assess efficacy of $\mathrm{HY}$ more rigorously are still not available. In spite of these facts, officials are currently advocating use of hydroxychloroquine (HY) for treatment and even prevention of COVID-19. In view of this situation and of the importance of correct interpretation of antibody profiles for planning preventive measures for COVID-19, we would like to bring the attention of readers to studies that raise concerns about the possible impact of HY upon antibody responses to SARS-CoV-2.

\section{IMPACT OF CHLOROQUINE AND DERIVATIVES ON RESPONSES TO VACCINES AND ANTIGEN PRESENTATION}

In 1986, Pappaionaou et al. (4) recalled the tragic story of a Peace Corps worker in Kenya who succumbed to rabies after being bitten by her rabies-infected pet dog despite having received a full regimen of human diploid-cells rabies vaccine 6 months prior to the bite. The subject had been vaccinated while receiving chloroquine as prophylaxis for malaria. Prompted by this finding, Pappaionaou et al. carried out a randomized controlled trial that showed that chloroquine suppressed antibody responses to the rabies vaccine (4). Subsequently, Fryauff et al. demonstrated a similar effect of chloroquine, but not of primaquine, on antibody responses to tetanus and diphtheria vaccines (5). More recently, Endy et al. showed that antibody responses of individuals vaccinated with a purified chick embryo cell rabies vaccine, given on a postexposure prophylaxis schedule, were significantly lower in individuals receiving chloroquine compared with controls (6).

$\mathrm{HY}$ and chloroquine are lysosomotropic drugs that increase the $\mathrm{pH}$ of the lysosome, thus affecting functions of proteins involved in antigen presenting pathways and in B-cell activation (7). To the best of our knowledge, there are no new facts in the scientific and medical literature that indicate that the same mechanism could not operate in HY-treated patients suffering from COVID-19 and negatively impact their SARS-CoV-2-specific antibody responses. Indeed, recent findings indicate that some individuals, including hospitalized patients, who have recovered from COVID-19 have not made vigorous IgG antibody responses. 
However, the most comprehensive publications addressing antibody responses, wherein study subjects presented viability in levels of IgG antibody responses, have not detailed the treatment regimens delivered to the subjects (8-11).

\section{DISCUSSION}

Plans for employing immunity profiles against SARS-CoV2 to relax social distancing and other epidemic mitigation measures and to create "immunity passports" to control spread of COVID-19 have recently been questioned by the World Health Organization because of uncertainty regarding antibody responses (12). As more needs to be learned about the role of antibodies in recovery from and protection

\section{REFERENCES}

1. Geleris J, Sun Y, Platt J, Zucker J, Baldwin M, Hripcsak G, et al. Observational study of hydroxychloroquine in hospitalized patients with Covid-19. N. Engl. J. Med. (2020) 382:2411-8. doi: 10.1056/NEJMoa20 12410

2. Rosenberg ES, Dufort EM, Udo T, Wilberschied LA, Kumar J, Tesoriero J, et al. Association of treatment with hydroxychloroquine or azithromycin with in-hospital mortality in patients with COVID-19 in New York State. JAMA. (2020) 323:2493-502. doi: 10.1001/jama.2020.8630

3. Mehra MR, Desai SS, Ruschitzka F, Patel AN. Hydroxychloroquine or chloroquine with or without a macrolide for treatment of COVID-19: a multinational registry analysis. Lancet. (2020) 395:e102. doi: 10.1016/S0140-6736(20)31180-6

4. Pappaioanou M, Fishbein DB, Dreesen DW, Schwartz IK, Campbell GH, Sumner JW, et al. Antibody response to preexposure human diploid-cell rabies vaccine given concurrently with chloroquine. N Engl J Med. (1986) 314:280-4. doi: 10.1056/NEJM198601303140504

5. Fryauff DJ, Cryz SJ, Widjaja H, Mouzin E, Curch LW, Sutamihardja $\mathrm{MA}$, et al. Humoral immune response to tetanus-diphtheria vaccine given during extended use of chloroquine or primaquine malaria chemoprophylaxis. $J$ Infect Dis. (1998) 177:1762-5. doi: $10.1086 / 517441$

6. Endy TP, Keiser PB, Cibula D, Abbott M, Ware L, Thomas SJ, et al. Effect of antimalarial drugs on the immune response to intramuscular rabies vaccination using a postexposure prophylaxis regimen. J Infect Dis. (2020) 221:927-33. doi: 10.1093/infdis/jiz558

7. Schrezenmeier E, Dörner T. Mechanisms of action of hydroxychloroquine and chloroquine: implications for rheumatology. Nat Rev Rheumatol. (2020) 16:155-66. doi: 10.1038/s41584-020-0372-x

8. To KK, Tsang OT, Leung WS, Tam AR, Wu TC, Lung DC, et al. Temporal profiles of viral load in posterior oropharyngeal saliva against infection with SARS-CoV-2, the impact of $\mathrm{HY}$ and other treatment regimens on antibody responses requires systematic evaluation.

\section{AUTHOR CONTRIBUTIONS}

All authors listed have made a substantial, direct and intellectual contribution to the work, and approved it for publication.

\section{FUNDING}

This work was supported by Fundação de Amparo à Pesquisa do Estado de São Paulo (FAPESP) (Grant Number 2020/09093-5 to IM).

samples and serum antibody responses during infections by SARS-CoV2: an observational cohort study. Lancet Infect. Dis. (2020) 20:56574. doi: 10.1016/S1473-3099(20)30196-1

9. Ni L, Ye F, Cheng ML, Feng $\mathrm{Y}$, Deng YQ, Zhao $\mathrm{H}$, et al. Detection of SARS-CoV-2-specific humoral and cellular immunity in COVID-19 convalescent individuals. Immunity. (2020) 52:971-77. doi: 10.1016/j.immuni.2020.04.023

10. Beavis KG, Matushek SM, Abeleda APF, Bethel C, Hunt C, Gillen S, et al. Evaluation of the EUROIMMUN anti-SARS-CoV-2 ELISA assay for detection of IgA and IgG antibodies. J Clin Virol. (2020) 129:104468. doi: $10.1016 /$ j.jcv.2020.104468

11. Huang AT, Garcia-Carreras B, Hitchings MDT, Yang B, Katzelnick LC, Rattigan SM, et al. A systematic review of antibody mediated immunity to coronaviruses: antibody kinetics, correlates of protection, and association of antibody responses with severity of disease. Infect Dis. (2020). doi: 10.1101/2020.04.14.20065771. [Epub ahead of print].

12. World Health Organization. Scientific Brief. "Immunity passports" in the context of COVID-19. (2020). Available online at: www.who.int/newsroom/commentaries/detail/immunity-passports-in-the-context-of-covid-19. doi: 10.15557/PiMR.2020.0024

Conflict of Interest: The authors declare that the research was conducted in the absence of any commercial or financial relationships that could be construed as a potential conflict of interest.

Copyright (c) 2020 de Miranda Santos and Costa. This is an open-access article distributed under the terms of the Creative Commons Attribution License (CC BY). The use, distribution or reproduction in other forums is permitted, provided the original author(s) and the copyright owner(s) are credited and that the original publication in this journal is cited, in accordance with accepted academic practice. No use, distribution or reproduction is permitted which does not comply with these terms. 